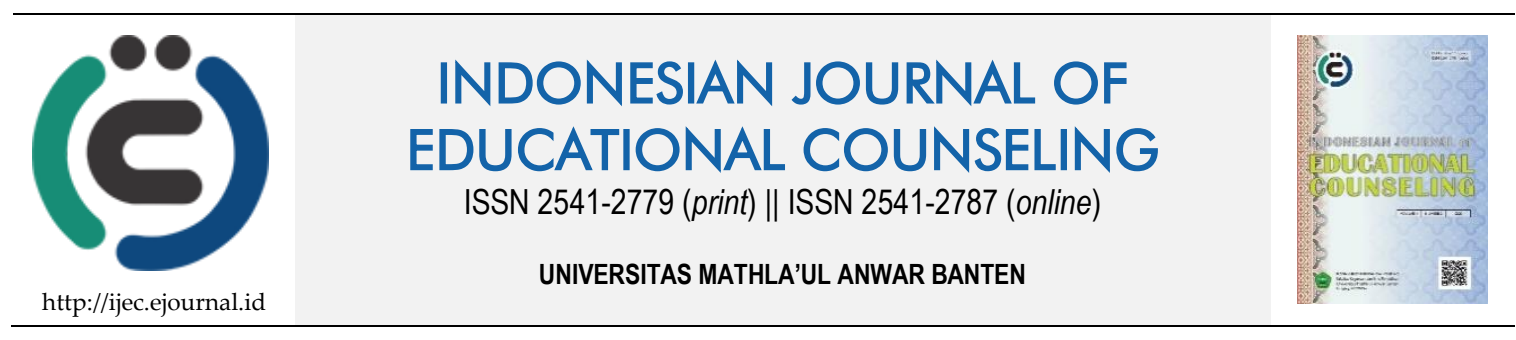

Research Based Article

\title{
Pengembangan Instrumen Dokumentasi Catatan Potensi Siswa Berdasarkan Manajemen Risiko dalam ISO 9001:2015
}

Arie Purwanto ${ }^{1}$, Palasara Brahmani Laras ${ }^{2}$

1,2 Universitas Mercu Buana Yogyakarta, Indonesia

\begin{tabular}{|c|c|}
\hline Article History & ABSTRACT \\
\hline $\begin{array}{l}\text { Received: } 24.02 .2020 \\
\text { Received in revised form: } \\
02.06 .2020 \\
\text { Accepted: } 25.06 .2020 \\
\text { Available online: } 30.07 .2020\end{array}$ & $\begin{array}{l}\text { DEVELOPMENT OF INSTRUMENTATION DOCUMENTATION OF } \\
\text { POTENTIAL STUDENTS BASED ON RISK MANAGEMENT IN ISO 9001: } \\
\text { 2015. This dedication is based on the devotion in the documentation of students' } \\
\text { potential risks. The purpose of this service is to help teachers, especially } \\
\text { guidance and counseling teachers, be able to measure and document the } \\
\text { potential risks experienced by their students. In addition, this instrumen was } \\
\text { deliberately developed so that it is expected to be able to make a positive } \\
\text { contribution to the teacher in designing classroom learning. By using this } \\
\text { instrumen teachers are expected to also be able to choose and use learning } \\
\text { models that are in accordance with the results of the analysis that has been done. } \\
\text { From the service that has been done, it is obtained that } 92 \% \text { of teachers strongly } \\
\text { agree with the holding of this service activity. Further analysis shows that there } \\
\text { is a real difference in understanding between before and after with a p-value of } \\
0.00 \text { with a correlation between the differences of } 0.816 \text {. It can be said that } \\
\text { assistance is effective in answering partner problems. }\end{array}$ \\
\hline
\end{tabular}

KEYWORDS: Risk Management, Potential Student.

DOI: 10.30653/001.202042.127

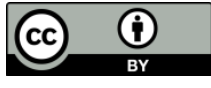

This is an open access article distributed under the terms of the Creative Common Attribution 4.0 International License, which permits unrestricted use, distribution, and reproduction in any medium, provided the original work is properly cited. ๑) 2020 Arie Purwanto, Palasara Brahmani Laras.

\section{PENDAHULUAN}

Bimbingan dan konseling sebagai bagian integral dari pendidikan yang berperan dalam proses membantu peserta didik untuk dapat mandiri dan mampu mengembangkan potensi yang ada. Hal ini sesuai tujuan bimbingan dan konseling yang diungkapkan oleh Natawidjaja (Yusuf, 2009, p. 38) bahwa bimbingan dan konseling memberikan bantuan kepada siswa guna mencapai kehidupan yang bermakna dan berbahagia baik secara personal maupun sosial. Untuk itu prean dari guru bimbingan dan konseling yang professional sangat dibutuhkan guna mewujudkan tujuan dari pendidikan.

Salah satu bentuk kinerja guru bimbingan dan konseling/konselor di sekolah yaitu dapat melakukan manajemen bimbingan dan konseling. Nurihsan (2006, p. 61) bahwa

${ }^{2}$ Corresponding author's address: Program Studi Bimbingan dan Konseling Universitas Mercu Buana Yogyakarta; Jl. Raya WatesJogjakarta, Karanglo, Argomulyo, Kec. Sedayu, Bantul, Daerah Istimewa Yogyakarta 55752, Indonesia. Email: palasara@ mercubuanayogya.ac.id 
layanan bimbingan dan konseling tidak mungkin tercipta, terselenggara, dan tercapai apabila tidak memiliki suatu sistem manajemen yang bermutu, jelas, sistematik, dan terarah. Pada dasarnya manajemen dalam layanan bimbingan dan konseling dilakukan untuk memberikan layanan bimbingan dan konseling yang bermutu, yaitu layanan yang mampu mengintegrasikan, mendistribusikan, mengelola, dan mendayagunakan program, personil, fasilitas dan pembiayaan layanan bimbingan dan konseling secara optimal agar dapat mengembangkan seluruh potensi peserta didik.

Manajemen bimbingan dan konseling adalah segala aktivitas yang dimulai dari perencanaan, pengorganisasian, pelaksanaan dan evaluasi di bidang bimbingan dan konseling. Perencanaan sebagai langkah awal dalam manajemen Bimbingan dan Konseling (BK) sangat berpengaruh pada hasil akhir dari pelayanan yang diberikan. Untuk itu melakukan perencanaan dalam manajemen merupakan langkah awal dalam memberikan sebuah layanan yang tepat guna dan sesuai dengan kebutuhan. Menurut Kauffman (Sugiyono, 2011, p. 32) "perencanaan adalah suatu proses penentuan tujuan atau sasaran yang hendak dicapai dan menetapkan jalan serta sumber yang digunakan untuk mencapai tujuan seefektif dan seefisien mungkin". Tanpa adanya suatu perencanaan, maka tujuan program yang dicapai tidak memiliki arah yang jelas. Perencanaan diawali pada hasil asessmen yang digunakan untuk membuat program terhadap klien yang membutuhkan layanan konseling.

Asesmen digunakan untuk mengetahui kebutuhan peserta didik sangat berpengaruh pada hasil layanan yang diberikan oleh guru BK dan berpengaruh pada perencanaan program BK, seperti yang dikemukakan oleh Yusuf. (2009, p. 70) "Konselor perlu mengidentifikasi dan merumuskan kebutuhan, dan karakteristik atau tugas-tugas perkembangan peserta didik, sebelum merumuskan tujuan dan rancangan program bimbingan dan konseling". Dilihat dari pernyataan tersebut seorang konselor atau guru BK dalam perencanaan program harus melakukan identifikasi kebutuhan siswa sebagai data awal penyusunan program. Apabila konselor tidak melakukan asesmen kebutuhan maka program yang disusun tidak sesuai dengan kebutuhan siswa dan penanganan permaslahan yang diberikan guru BK kurang maksimal.

Menurut Uno dan Koni (2014:2) assessment sebagai proses untuk mendapatkan informasi dalam bentuk apapun yang dapat digunakan untuk dasar pengambilan keputusan tentang siswa, baik yang menyangkut kurikulum, program pembelajaran, Iklim sekolah maupun kebijakan-kebijakan sekolah. Hal senadadengan pendapat Abdurahman (2003, p. 60) asesmen merupakan suatu proses pengumpulan informasi terkait kesulitan belajar siswa yang akan digunakan sebagai pertimbangan dalam merencanakan program pembelajaran untuk anak tersebut. Dalam Rifai dan Anni (2011, p. 252) menjelaskan bahwa asesmen merupakan suatu proses pengumpulkan informasi yang sistematik melalui pengukuran pengetahuan, keterampilan, sikap dan keyakinan peserta didik. Sedangkan Supratiknya (2011, p. 116) "needs assessment atau asesmen kebutuhan adalah proses mengumpulkan informasi terhadap klien untuk mengetahui kebutuhan klien".

Pemberian asesmen kebutuhan dalam bimbingan dan konseling dapat dilakukan melalui dua teknik yakni tes dan non-tes. Hal ini sejalan dengan pendapat Supriatna (2013:203) yang menguraikan bahwa teknik yang dapat digunakan untuk mengumpulkan data atau informasi terkait dengan peserta didik dapat dilakukan dengan dua pendekatan yaitu pendekatan tes dan non tes. Alat tes bermanfaat untuk memperoleh data tentang individu, sedangkan alat- non test diperlukan sebagai alat pengumpul data, khususnya 
dalam hal memperoleh data sosial yang relevan, untuk menyimpan serta mengolah keseluruhan data yang masuk (Winkel \& Hastuti, 2006, p. 269). Ada berbagai jenis alat instrumen untuk mengidentifikasi masalah individu, salah satu contoh alat non-test yang dapat membantu kinerja guru bimbingan dan konseling/konselor untuk mengidentifikasi kebutuhan siswa yakni Daftar Cek Masalah (DCM).

Menurut Aiken (Sutoyo, 2009, p. 117) menjelaskan bahwa daftar cek masalah merupakan instrument yang berbentuk psikometrik yang sederhana, memuat kata-kata, kalimat atau peryataan-peryataan yang berisi kegiatan-kegiatan atau pikiran-pikiran yang menjadi fokus pengamatan. Sedangkan menurut rahardjo dan gunanto (2011, p. 69) daftar cek masalah merupakan daftar cek yang khusus disusun untuk mengungkap suatu permasalahan yang sedang dialami siswa maupun masalah yang pernah dialami oleh siswa. Alat instrumen ini membantu guru bimbingan dan konseling/konselor untuk mengungkap masalah siswa berdasarkan pernyataan-pernyataan yang telah disediakan, Setiap pernyataan itu mengungkap permasalahan siswa yang berkaitan dengan masalah pribadi, sosial, belajar dan karier. Dengan adanya item pada alat test DCM diharapkan siswa bisa terbantu untuk menemukan masalah yang dihadapinya, maka dibutuhkan suatu stimulus untuk mengungkap masalah yang mereka rasakan.

Melalui alat pengumpulan data DCM ini juga dapat memudahkan guru bimbingan dan konseling/konselor untuk menganalisis dan pengambilan keputusan dalam menyusun program bimbingan, karena masalah yang dialami peserta didik dapat terditeksi dengan jelas dan dapat di preoritaskan mana masalah yang harus diutamakan untuk diselesaikan. Sejauh ini pengalaman pengabdi sekaligus peneliti di bidang intrumen pengembangan assesmen, terdapat banayak instrumen yang telah dikembangkan. Namun demikian dari sejumlah instrumen tes yang ada, terdapat instrumen yang masih bersifat klasik atau tidak berbasis teknologi. Disamping itu perkembangan dunia digital yang sangat pesat memungkinkan guru bimbingan dan konseling/konselor yang dalam hal ini difokuskan terhadap guru bimbingan dan konseling membutuhkan segenap instrumen-instrumen tes yang sesuai dengan kebutuhan jaman. Hal ini sangat penting terutama dalam melakukan perencanaan yang dilakukan oleh seorang guru bimbingan dan konseling untuk deteksi awal masalah potensial yang dihadapi oleh siswanya.

Berdasarkan asumsi tersebut di atas, studi ini ditujukan untuk mengembangkan analisis instrumen berupa daftar cek masalah yang terdigitalisasi. Gagasan utama dalam studi ini adalah memodifikasi alat instrumen tes untuk mempermudah seorang guru mendeteksi dan mendokumentasikan potensi risiko yang dimiliki siswa dalam pengimplementasian standar internasional ISO 9001:2015 tentang manajemen sistem sehingga menjadi efektif dan efisien.

Pengembangan instrumen dengan standar ISO 9001:2015 berbasis manajemen risiko. Pemikiran berbasis risiko menggerakkan sebuah organisasi untuk menentukan faktorfaktor yang dapat menyebabkan proses-proses menjadi menyimpang dari hasil yang direncanakan, untuk menempatkan kontrol pencegahan untuk meminimalkan efek negatif dan memaksimalkan penggunaan peluang yang muncul. Dasar inilah yang mendorong studi ini untuk mengembangkan instrumen yakni pengembangan daftar cek masalah berbasis Manajemen Risiko berdasarkan ISO 9001:2015. Output yang dihasilkan adalah aplikasi program dalam bentuk excel yang dapat digunakan oleh guru bimbingan konseling dalam mendeteksi masalah potensial siswa untuk kemudian dapat segera ditangani. Output aplikasi program berupa daftar masalah-masalah potensial yang 
dialami siswa mulai dari yang tertinggi hingga terendah. Hal ini dimungkinkan sehingga guru bimbingan konseling dapat dengan mudah mendeteksi potensi negatif yang dialami siswanya sehingga dapat dimungkan untuk mengembangkan dan memilih model yang tepat dalam pembelajaran.

\section{METODE}

Metode yang digunakan dalam penelitian ini adalah metode Research and Development (RED). Menurut Sugiono (2010:407) metode R\&D adalah metode penelitian yang digunakan untuk menghasilkan produk tertentu, dan menguji keefektifan produk tersebut. Desain R\&D ini dengan desain instruksional ADDIE (Analysis-Desain-DevelopImplement-Evaluate) yang dikembangkan oleh Reiser dan Mollenda (1990-an) merupakan model desain pembelajaran/pelatihan yang bersifat generik menjadi pedoman dalam membangun perangkat dan infrastruktur program pelatihan yang efektif, dinamis dan mendukung kinerja pelatihan itu sendiri. Sehingga membantu instruktur pelatihan dalam pengelolaan pelatihan dan pembelajaran (Pargito, 2010:46). Dalam studi ini metodologi yang digunakan dimaksudkan untuk menghasilkan produk berupa aplikasi program yang mampu mengidentifikasi dan mendokumentasi potensi risiko siswa. Adapun langkah-langkah yang ditempuh sebagai berikut:

\section{Analisis}

Dalam tahap analisis ini dapat diketahui bahwa instrumen Daftra Cek Masalah (DCM) yang digunkan diangggap kurang detail dalam menganalisa potensi risiko. Dalam banyak instrument sejenis ditemukan tidak adanya likelihood (seberapa sering risiko tersebut terjadi) dan severity (seberapa besar dampak potensi risiko yang dialami siswa). Disamping itu tidak atau memang jarang ditemukan aspect, impact, dan mitigation yang dilakukan oleh seorang konselor. Dengan demikian diperlukan adanya instrumen yang mampu mendokumentasikan keseluruhan aktifitas yang dilakukan. Instrument yang dikembangkan, diharapkan dapat membantu guru bimbingan dan konseling dalam mengantisipasi masalah-masalah yang mungkin dapat muncul di kemudian hari.

\section{Desain}

Berdasarkan analisis yang dilakukan maka dibutuhkan suatu produk instrument yang handal dalam analisis potensi siswa. Produk yang akan diciptakan yakni instrumen pengembangan dari Daftar Cek Masalah (DCM). Instrument yang baru terdiri dari potensi masalah, assessment yang merupakan fungsi dari likelihood dan severity, aspect, impact, dan mitigation action. Instrumen yang baru diharapkan mampu mendokumentasikan keseluruhan potensi risiko yang mungkin akan muncul.

\section{Pengembangan}

Proses pengembangan diawali dengan mengumpulkan daftar risiko, Daftar risiko yang digunakan mengangkat 10 (sepuluh) topik yakni, kesehatan, ekonomi, hobi dan rekreasi, kehidupan sosial, kehidupan, keluarga, agama dan moral, lingkungan, sekolah, kurikulum sekolah, cita-cita dan masa depan, dan asmara. Berdsarkan 10 (sepuluh) topik yang diangkat, ditemukan 200 (dua ratus) masalah yang mungkin dialami siswa. Distribusi masalah yang ada, disesuaikan dengan topik topik yang bersesuaian. Setelah daftar topik dengan distribusi daftar masalah telah ditetapkan maka dilakukan uji validitas dan reliabilitas konten. Uji statistik yang digunakan dalam uji validitas dan reliabilitas secara berurut menggunkaan Kendall Tau-b dan Cronbach's Alpha. Pengujian 
validitas dilakukan oleh sebanyak 10 (sepuluh) validator ahli baik ahli dari Bimbingan dan Konseling serta ahli dalam pengembangan instrument. Evaluasi dan perbaikan atas proses penlilaian instrumen dilakukan hingga instrument dirasa cukup valid dan dapat diimplementasikan.

\section{Implementasi}

Instrument yang telah dibuat kemudian dimplementasikan sesuai tujuan dari pembuatan produk. Kegiatan implementasi dilakukan pada guru-guru bimbingan konseling dan guru mata pelajaran. Target awal implementasi produk adalah sebanyak 20 (dua puluh) guru yang mewakili guru bimbingan dan konseling serta guru mata pelajaran.

\section{Evaluasi}

Kegiatan evaluasi dilakukan dengan mempertimbangkan masukan dari pengguna yang dalam kasus ini adalah guru bimbingan dan konseling serta guru mata pelajaran. Metode yang dilakukan dalam evaluasi ini adalah menggunakan metode angket. Secara umum angkat terdiri dari 10 (sepuluh) item pernyataan. Analisis evaluasi instrument angket yang digunakan adalah analisis skala Likert yang terdiri dari 5 (lima) opsi jawaban. Kegiatan evaluasi dilakukan guna meningkatkan kualitas produk yang dihasilkan. Peningkatan kualitas yang dimaksud dimungkinkan dapat berupa perbaikan sistem, statistik yang digunakan, dan daftar masalah ataupun topik yang mungkin belum dicantumkan dalam instrumen.

\section{HASIL DAN PEMBAHASAN}

Uji validitas dan reliabilitas instrument dilakukan untuk setiap topik yang diangkat. Analisis butir yang biasa dilakukan tidak dilakukan mengingat indikator yang terlalu banyak dalam instrument yang digunakan. Hal ini dapat dianggap sebagai kewajaran dalam analisis instrument tes dengan menganggap topik sebagai indikator yang diuji. Validator yang digunakan dalam instrument ini adalah sebanyak 10 orang pakar. Pakar yang digunakan adalah pakar bimbingan dan konseling serta ahli dalam pengembangan instrument. Dalam uji validitas ini analisis yang digunakan adalah analisis Kendall tau-b. Dengan mengambil nilai kesalahan sebesar $5 \%$ hasil pengujiann sisajikan dalam Tabel 1.

Tabel 1. Hasil uji validitas

\begin{tabular}{lllll}
\hline No & Masalah & r-value & p-value & Keterangan \\
\hline 1 & Kesehatan & 0.775 & 0.009 & valid \\
\hline 2 & Ekonomi & 0.725 & 0.014 & valid \\
\hline 3 & Hoby dan Rekreasi & 0.634 & 0.033 & valid \\
\hline 4 & Kehidupan Sosial & 0.829 & 0.005 & valid \\
\hline 5 & Kehidupan Keluarga & 0.862 & 0.003 & valid \\
\hline 6 & Agama dan Moral & 0.680 & 0.022 & valid \\
\hline 7 & Lingkungan Sekolah & 0.762 & 0.009 & valid \\
\hline 8 & Kurikulum Sekolah & 0.705 & 0.018 & valid \\
\hline 9 & Cita-cita dan masa Depan & 0.756 & 0.011 & valid \\
\hline 10 & Asmara & 0.828 & 0.005 & valid \\
\hline
\end{tabular}

Berdasarkan hasil pengujian validitas dapat diketahui bahwa keselurusan topik yang didistribusikan dalam sebanyak 200 masalah yang diangkat dapat dianggap valid. 
Selain itu analisis Cronbach's Alpha menunjukkan bahwa nilai reliabilitas yang dihasilkan adalah sebesar 0.958 yang dapat diartikan sangat baik. Dengan demikian instrumen yang dibuat dapat dikatakan tepat dan konsisten.

Analisis kebermanfaatan kegiatan pengabdian kepada masyarakat dilakukan dengan menyebarkan angket. Angket yang disebarkan terdiri dari 10 butir pertanyaan. Tujuan dari penyebaran angket adalah untuk bahan evaluasi kebernanfaatan instrumen yang dilakukan. Analisis yang digunakan yakni analisis skala Likert dengan metode persentase. Adapun hasil yang diperoleh disajikan dalam Tabel 2.

Tabel 2. Analisis Kebermanfaatan Kegiatan

\begin{tabular}{lll}
\hline No & Pernyataan & Rate skor Likert \\
\hline 1. & $\begin{array}{l}\text { Kegiatan pelatihan dan pendampingan ini memberikan } \\
\text { wawasan kepada guru terkait pentingnya dokumentasi } \\
\text { potensi risiko siswa }\end{array}$ & 92 \\
\hline 2. & $\begin{array}{l}\text { Kegiatan pelatihan dan pendampingan ini memberikan } \\
\text { wawasan kepada guru tentang instrument dokumentasi } \\
\text { potensi risiko siswa }\end{array}$ & 94 \\
\hline 3 & $\begin{array}{l}\text { Kegiatan pelatihan ini membantu guru dalam menganalisa } \\
\text { dampak potensi risiko siswa baik individu maupun } \\
\text { kelompok }\end{array}$ & 90 \\
\hline 4 & Instrument yang diberikan mudah digunakan \\
\hline 5 & Pelatihan memudahkan guru dalam mengelola siswa \\
\hline 6 & $\begin{array}{l}\text { Pelatihan memudahkan guru dalam mengelola kelompok } \\
\text { siswa }\end{array}$ & 98 \\
\hline 7 & $\begin{array}{l}\text { Pelatihan memudahkan guru dalam menyusun model } \\
\text { belajar ataupun rencana belajar siswa }\end{array}$ & 92 \\
\hline 8 & $\begin{array}{l}\text { Guru sangat terbantu dengan adanya kegiatan pelatihan } \\
\text { dan pendampingan ini }\end{array}$ & 96 \\
\hline 9 & $\begin{array}{l}\text { Perlu ada kegiatan pelatihan dan pendampingan lanjutan } \\
\text { untuk meningkatkan prestasi belajar siswa }\end{array}$ & 94 \\
\hline 10 & $\begin{array}{l}\text { Perlu adanya pengembangan dan perbaikan instrument } \\
\text { yang diberikan }\end{array}$ & 96 \\
\hline
\end{tabular}

Berdasarkan Tabel 2 dapat diketahui bahwa secara umum hasil yang diperoleh dapat dikatakan sangat baik. Namun demikian pada item nomor 4 diperoleh nilai 84 yang dikategorikan dalam criteria baik. Hal ini dapat menjadi bahwan evaluasi bahwa pada dasarnya instrumen yang digunakan dimungkinkan kurang cukup handal dalam menganalisa konseling kelompok. Hal ini dikarenakan masih belum ditemukannya fungsi yang mudah untuk mneganalisa dan mendokumentasikan konseling kelompok. Pengguna harus menginput satu per satu statement siswa apabila ingin mengetahui nilai asesmen kelompok. Dengan demikian dapatdijadikan bahan evaluasi bahwa diperlukan program baru yang dapat mempermudah kegiatan guru dalam mendokumentasikan potensi risiko siswanya.

Analisis pemahaman guru juga dilakukan guna mengevaluasi program yang dilakukan. Adapun indikator dan hasil yang diperoleh disajikan dalam Tabel 3. 
Tabel 3. Analisis pemahaman

\begin{tabular}{llcc}
\hline \multirow{2}{*}{ No } & Pernyataan & \multicolumn{2}{c}{ Rata-rata pemahaman } \\
\cline { 2 - 4 } & $\begin{array}{l}\text { Apakah sekolah memiliki instrumen dokumentasi } \\
\text { siswa }\end{array}$ & 2 & 10 \\
\hline 2 & $\begin{array}{l}\text { Apakah Anda memahami pentingnya dokumentasi } \\
\text { potensi risiko siswa }\end{array}$ & 2 & 9 \\
\hline 3 & $\begin{array}{l}\text { Apakah pernah melakukan dokumentasi potensi } \\
\text { risiko siswa selama menjadi guru }\end{array}$ & 3 & 10 \\
\hline 4 & $\begin{array}{l}\text { Apakah guru melakukan pendekatan kepada siswa } \\
\text { sebelum menerapkan model atau pendekatan belajar } \\
\text { kepada siswa }\end{array}$ & 4 & 10 \\
\hline
\end{tabular}

Analisis yang sesuai untuk menunjukkan ada tidaknya perbedaan signifikan dari hasil yang diperoleh yakni mneggunakan uji paired-sample t-test. Dengan mengambil tingkat kesalahan sebesar $5 \%$ diperoleh bahwa terdapat perbedaan nyata anatara sebelum dan setelah pelatihan dengan korelasi sebesar 0.816 dan p-value sebesar 0.00 . Hal ini apat dikatakan bahwa pendampingan efektif dalam menjawab permasalahan mitra.

\section{SIMPULAN}

Uji paired-sample t-test dengan mengambil tingkat kesalahan sebesar 5\% diperoleh bahwa terdapat perbedaan nyata anatara sebelum dan setelah pelatihan dengan korelasi sebesar 0.816 dan p-value sebesar 0.00. Hal ini apat dikatakan bahwa pendampingan efektif dalam menjawab permasalahan mitra.

Sebesar 92\% guru sangat setuju dengan diadakannya kegiatan pengabdian ini. Pengabdian yang dilakukan sejauh ini mampu meningkatkan pemahaman mitra. Namun demikian, perlu diadakan perbaikan sistem terutama terkait dengan aplikasi yang digunakan dalam instrumen. Kedepan diharapkan dapat dibuat instrumen dengan aplikasi sistem yang lebih menarik dan handal ddalam menyelesaikan analisis. Hal ini diungkapkan karena dalam pengabdian ini masih ditemukan adannya kesulitan pengguna dalam mengaplikasikan instrumen dokumentasi.

\section{REFERENSI}

Abidin, Y. (2009). Guru dan pembelajaran bermutu. Bandung: Rizqi press.

Abdurahman, M. (2003). Pendidikan bagi anak kerkesulitan belajar. Jakarta: Rineka Cipta.

Nurihsan, A. J. (2006). Bimbingan dan konseling dalam berbagai latar kehidupan. Bandung: Refika Aditama.

Rahardjo, S., \& Gunanto. (2011). Pemahaman individu teknik non tes. Kudus: Universitas Muria Kudus.

Rifai, A., \& Anni, C. T. (2011). Psikologi pendidikan. Semarang: UNNES Press. 
Sugiono. (2010). Metode penelitian pendidikan pendekatan kuantitatif, kualitatif, dan RED. Bandung: Alfabeta.

Sugiono. (2011). Metode penelitian pendidikan (Pendekatan kualitatif, kuantitatif, dan RED). Bandung: Alfabeta.

Sugiono. (2016). Metode penelitian dan pengembangan (Research and development). Bandung: Alfabeta.

Supratiknya. (2011). Merancang program dan modul. Yogyakarta: Universitas Sanata Dharma.

Supriatna, M. (2011). Bimbingan dan konseling berbasis kompetensi. Jakarta: Rajagrafindo Persada.

Sutoyo, A. (2009). Pemahaman individu. Semarang: Widya Karya.

Winkel, W. S., \& Hastuti, S. (2006). Bimbingan dan konseling di instansi Pendidikan. Jakarta: Grasindo.

Yusuf, S. (2009). Program bimbingan dan konseling di sekolah. Bandung: Rizqi Press.

Uno, H. B., \& Koni, S. (2014). Assesment pembelajaran. Jakarta: Bumi Aksara. 